\title{
Tax Structure and Economic Growth: Middle-Income Asian Countries Analysis
}

\author{
Aisha Nazir ${ }^{1}$, Sofia Anwar ${ }^{2}$ and Samia Nasreen ${ }^{3}$
}

\begin{abstract}
The optimum design of a tax structure depends on various factors that differ from region to region. This research work aims to explore the relationship between tax structure (TS) and economic growth (EG) in middle-income (MI) Asian countries. To analyze this relation empirically, panel data for the period 1990-2017 of 20 Asian countries is collected and a two-step system GMM estimation technique is applied. Moreover, the existing tax structure of middle-income Asian countries is further divided into direct and indirect taxes to study its separate as well as combine effect on EG. Findings of separate tax analysis demonstrate that payroll $\&$ workforce and GST have a positive and significant while corporate, property, and international trade taxes show a negative impact on economic growth. Furthermore, in the combined analysis, the positive effect of indirect taxes counterbalances the negative impact of direct taxes, making consumption taxes more striking as compared to income taxes. These results suggest that to accomplish optimal tax structure design, corporate and trade taxes must be discouraged in middle-income Asian economies if the objective of the countries is to achieve economic growth.
\end{abstract}

Keywords: Tax Structure, Middle-income Asian Countries, Direct \& Indirect Taxation, GMM, Panel Data.

JEL Classification: C23, E62, H24, H25.

\section{Introduction}

Taxes play a vital role in achieving the country's development objectives because they provide revenue to fund the needs of physical and social infrastructure and foster a stable, investment-friendly environment (Grdinić et al., 2017). A combination of tax management and all related policies is called a tax system and achieving an efficient tax system is essential for comprehensive economic growth strategies and the overall administration of the public sector (Martinez-Vazquez, 2014). An effective and favorable tax system can split the fiscal burden between

\footnotetext{
${ }^{1} \mathrm{PhD}$ Scholar, Department of Economics, Government College University Faisalabad.

${ }^{2}$ Professor and Chairperson, Department of Economics, Government College University Faisalabad.

${ }^{3}$ Associate Professor in the Department of Economics, Lahore College for Women University, Lahore.

Corresponding authors Email: samia.nasreen@1cwu.edu.pk
} 
people and state; build up efficient resources that lead towards less reliance on foreign loans; improve governance and hence increase economic growth (Atems, 2015; Ali et al., 2014; Bujang et al., 2013; Chaudhary \& Munir, 2010; Dioda, 2012; Karimi et al., 2016; Stoilova, 2017; Torgler \& Schneider, 2009; Xing, 2012).

Taxation is defined as a price imposed on people by the state for providing services and facilities to its public. Tax is not a voluntary payment or contribution, actually it is a compulsory and somehow forceful payment to the government (Islam, 2016). Currently, tax revenue is one of the main sources of the country's total revenue in all developed states of the globe and therefore it is a major determinant of EG for a country. The accessible economic assets are inadequate, so if a state wants to increase its expenditures it normally means a reduction in private consumption. It is said 'what the government gives it must first take away'. In any country, if tax revenues are not up to the mark it may lead to the deteriorating impact on EG in the form of growing fiscal deficit, internal \& external borrowing, debt servicing, and foreign dependence. Hence, it will not be surprising if all fiscal programs in developing countries are started with lowering the tax rate, broadening the tax base, and improving transparency in the tax system. Till now taxation is the most efficient way of transferring wealth from the private to the public sector (Chaudhry \& Munir, 2010).

The amount that gets collected by the government as tax revenue around different times has been a subject of fierce debate. Major factors that can cause changes in tax revenue are the growth/development status, the structure of an economy, FDI, and trade (Karagöz, 2013; Pessino \& Fenochietto, 2010; Bird et al., 2008; Gupta, 2007; Piancastelli, 2001; Cassou, 1997). More other factors like financial policies, exchange rate, inflation, level of public debt, institutional factors, and government efficiency are also considered as important determinants of taxrevenue (Castro \& Camarillo, 2014; Terra \& Hudson, 2004; Tanzi, 1989). Countries where governments are inefficient to collect an adequate amount of taxes from their masses and underground economies will ultimately lead to instability. This can further escalate social problems, deteriorate social \& physical capital and overall confidence in the economy that can worsen the institutional situations (Amoah, 2014; Le et al., 2012; Katsios, 2006).

The tax burden in Asian countries is among the lowest in the world, as is shown in Table-1 \& Figure-1. Tax to GDP ratio in developed countries like France (46\%), UK (32.9\%), USA (26.78\%), and Denmark (45\%) is much greater than that of MI Asian countries; Pakistan (11.4\%), India (17.5\%), Malaysia (12.96\%). The poor tax revenue collection from MI Asian countries demand formulating a 
structure of tax reforms that would directly or indirectly cause economic growth and improve governance.

Table 1: Tax revenue (\%) in Middle-Income Asian and other countries

\begin{tabular}{llllll}
\hline MI countries & Tax/GDP & MI countries & Tax/GDP & Developed-countries & Tax/GDP \\
\hline Armenia & 21.24 & Azerbaijan & 14.21 & USA & 26.78 \\
India & 17.55 & Malaysia & 12.96 & UK & 32.96 \\
Thailand & 17.28 & Sri Lanka & 12.60 & France & 46.12 \\
Kazakhstan & 16.59 & Pakistan & 11.40 & Germany & 37.94 \\
Lebanon & 15.35 & Indonesia & 9.89 & Austria & 41.86 \\
Vietnam & 14.34 & Bangladesh & 8.41 & Denmark & 45.43 \\
Philippines & 14.24 & Iran & 7.12 & & \\
\hline
\end{tabular}

Source: ICTD by United Nation University (UNU-WIDER) Government Revenue-2017.

Figure 1: Direct \& Indirect Taxation in the USA, ASIA and OECD Countries

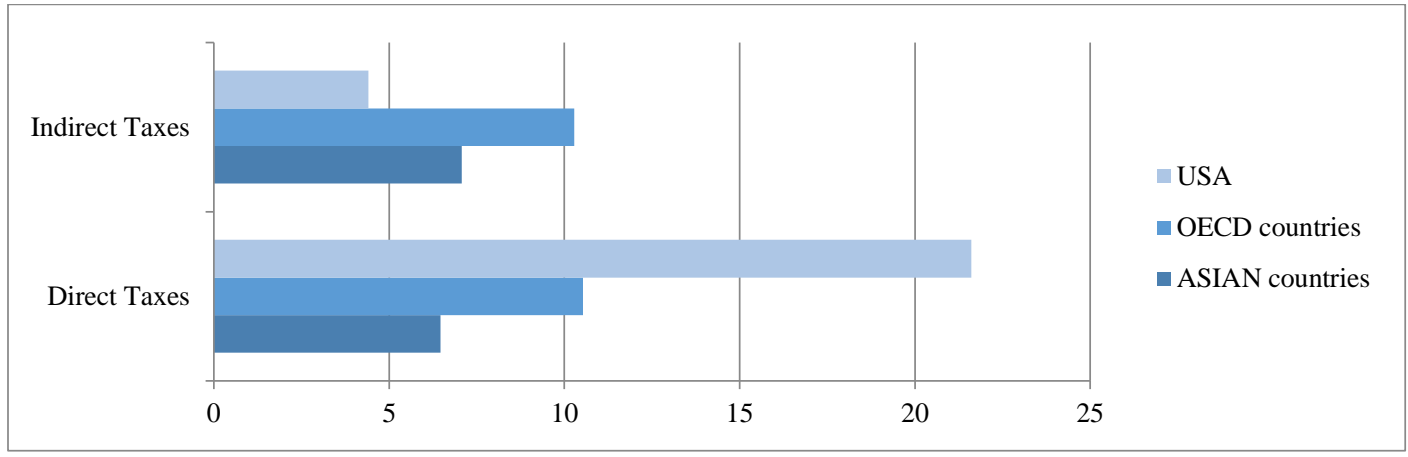

Source: ICTD by United Nation University (UNU-WIDER) Government Revenue 2017

MI countries of Asia can, specifically, perform a major role in the process of tax reforms because these countries suffer from unfair tax administration, wealth, and income inequalities. It is also considered that MI countries have a considerable influence on their neighboring countries. Moreover, these countries have more capacity to design an appropriate design of tax structure than the low-income countries because taxpayers in these countries are becoming more politically vigilant and conscious with the time (Moore \& Schneider, 2004). The structure of existing taxes in MI Asian countries is presented in Figure-2

Although the relationship between tax structure and economic growth has been rigorously estimated in the existing literature, however, it mostly covers the tax system of developed and advanced regions or OECD countries. Only a few comprehensive studies existed in the case of middle-income countries, So this study makes an attempt to cover this research gap in the existing literature by following 
ways 1) A comprehensive analysis of all major taxes (separately \& combined) levied in middle-income Asian countries is carried out to estimate the optimal tax structure for economic growth which will ultimately provide a way forward to policymakers. 2) This study uses broad-based data from ICTD-Government Revenue Dataset (ICTD-GRD). It is a new dataset for tax variables that gives access to a more reliable, consistent, and wide-ranging data basis, especially for the crosscountry analysis. 3) System GMM dynamic panel approach is used to solve the problem of endogeneity and simultaneity that emerge due to the correlation of tax variables with other explanatory variables and the error terms.

Figure 2: Tax Structure in Middle-Income Asian countries

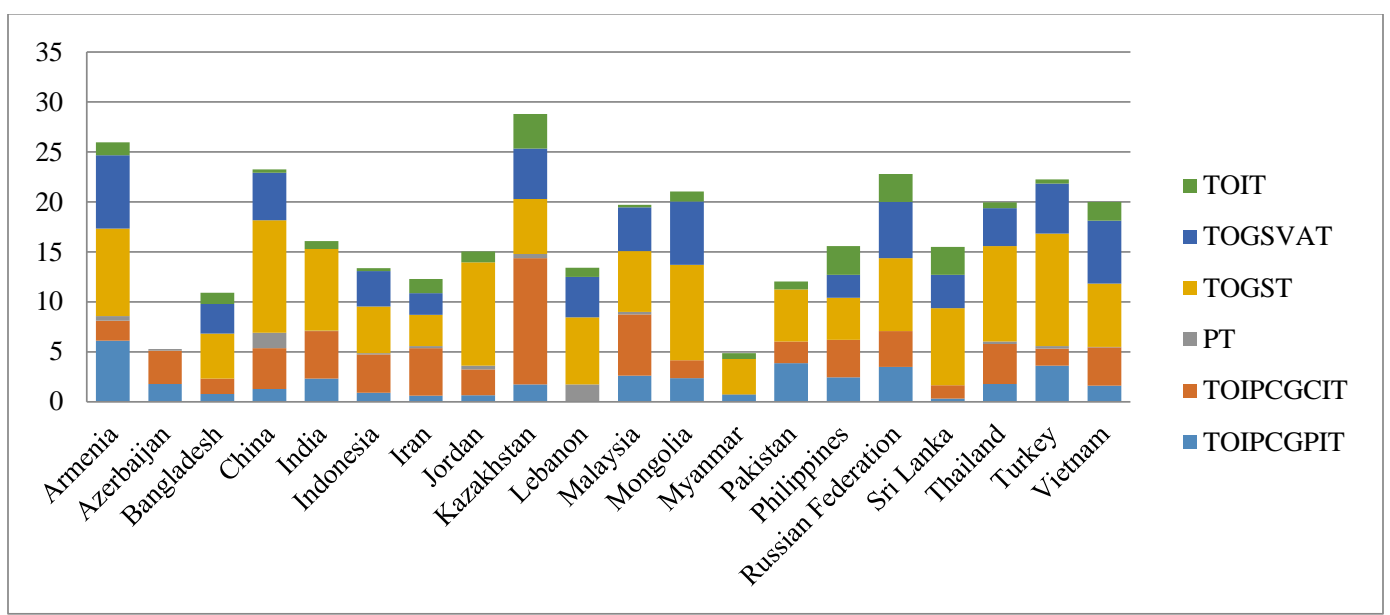

Source: ICTD by (UNU-WIDER) Government Revenue-2017.

The remaining paper is arranged as follows: Section-2 briefly reviews the literature on the tax structure. Section-3 describes variables and data sources. The empirical technique employed in the analysis is discussed in Section-4. Section-5 explains the result and discussion of the analysis and section- 6 presents concluding remarks.

\section{Literature Review}

The relationship between EG and level/structure of taxation in different countries covering different periods using different datasets is widely analyzed previously but no consensus can be made about the sort of the relationship from these empirical analyses (McNabb \& LeMay-Boucher, 2015; Paparas et al., 2015; Agell et al., 2006; Fölster \& Henrekson, 2001; Levine \& Renelt, 1992; Barro, 1990, 1991). 
The effect of tax structure on economic growth for more than a hundred countries that were divided into high, low, and middle countries is assessed by Yanikkaya and Turan (2020). GMM estimation technique is employed in this research and results show that shifting from consumption to income taxes is preferred for low-income countries' growth rate. Stoilova (2017) also empirically analyzed the effect of tax structure (TS) on the EG in $28 \mathrm{EU}$ member states. Findings show that economic recession/depression reduce government spending, balance the financial plan, and establish a tax structure that is helpful to EG. The study concluded that personal income tax (PIT) and social contributions had significant and direct but VAT had indirect/reverse effect on EG. However, AcostaOrmaechea et al. (2019) findings were contrary to that of Stoilva (2018) as it was found by conducting Pooled Mean Group estimation (PMG) that personal income and social security contribution reduce economic growth while property and consumption taxes promote the growth for high and middle-income economies.

Widmalm (2001) also investigated the tax structure-growth relationship in OECD countries. In this study, the tax progressivity variable is also calculated by regressing total tax revenue with GDP. Results show that revenue generated from PIT is inversely correlated with EG while consumption tax is growth augmenting because it is less harmful than other alternative tax bases. Adkisson and Mohammed (2014) studied fifty states of the USA for the period 2004-2010, this period also comprised of the great economic depression year centered in 2008. Findings of the empirical analysis showed that tax structure has a statistically significant relationship with short term EG for the period of 2004-2010. However, the marginal effects of different taxes are varied and not very large on EG but detectable. So, this evidence states that countries that have decreasing economic growth will not make big changes in tax structures if the objective is to enhance EG. Besides, using stationarity and cointegration estimation techniques on time series data of period 1994-2016, Juliana (2018) has found a positive and significant association between all component taxes and EC while researching country Nigeria.

Lee and Gordon (2005) analyzed that how tax-related strategies affect EG and concluded that PIT rates had no significant relation with economic growth while corporate tax rates were negatively related to EG and concluded that a $10 \%$ decrease in corporate tax rates would rise 1-2\% annual growth rates. For the study of tax structure, Djankov et al. (2010) concluded that corporate income tax (CIT) had a deteriorating effect on FDI, aggregate investment, and entrepreneurial activities. Aggregate investment to GDP ratio is reduced by $2 \%$ with the $10 \%$ increase in corporate taxation. Moreover, corporate taxes were positively associated with the shadow economy and negatively with economic growth. In the 
same spirit, many researchers conducted this study of the connection between EG and taxes and findings discovered that corporate taxes are risky for growth (Ferede \& Dahlby, 2019; Bakari 2018; Ojong et al., 2016; Zellner \& Ngoie, 2015; Xing, 2012).

Neog and Gaur (2020) investigated the tax-growth relationship but only in India using the ARDL approach for the time period 1980-2016 and get to know that income and excise taxes are not suitable for long-term economic growth. While corporate taxes are harmful to growth in both the short \& long run. Atems (2015) also analyzed the short \& long-run impact of tax on state EG. Results show that taxes have negative long \& short run spillover and total effects on EG. The longrun relationship between tax structure and EG is also estimated by Bujang et al. (2013) in developing and OECD countries for the 2000-2009 time-period. Its findings showed that the long-run relation between GDP \& tax structure and gross saving \& tax structure does not exist in developing states, but it exists in OECD countries. However, the long-run relation between tax and trade is present in developing countries and no evidence of this association was in OECD countries. Moreover, Arnold et al. (2011) estimated tax policies that help in overcoming an economic crisis and also facilitate in achieving long-run EG by using research data of 21 OECD countries for the year1971- 2004. Results showed that tax on immovable property is most beneficial on long-run GDP growth followed by consumption $\&$ property taxes.

Ojede and Yamarik (2012) estimated the short \& long-run impact of tax policies on state-level EG by using the pooled mean group estimation technique for 48 US states from 1967 to 2008 period. Findings report that income tax has no significant effect on EG in the short and long run. However, sales \& property taxes are negatively related to economic growth so has a detrimental effect on EG in the long run. Xing (2012) also analyzed the relation between the long-run level of income per capita and the composition of tax revenues for the 17 OECD countries. Property taxes are found to be affecting the economy positively after applying the pooled mean group estimation technique.

Prichard (2016) introduced a new dataset for tax variables by ICTD GRD, compared its effectiveness with the other prevalent tax data sets, and found it more transparent, comprehensive, and reliable especially for cross-country analysis. McNabb and LeMay-Boucher (2015) used the same data set from ICTD by GRD for over a hundred countries from 1980 to 2010. Findings show that international trade has no significant effect on EG and changes in direct taxes are neutralized by 
a parallel decrease in indirect taxes, by studying the data of advanced and poor countries.

Paparas et al. (2015) analyzed 15 EU countries to determine which fiscal policy is better for EG by using data for the period 1995-2008. Results concluded that state spending on human capital accumulation has an inverse but significant effect on EG and analyzing the other side of the budget it is found that distortionary taxes harmed EG. Moreover, this relation between Government size and EG is also conducted using data from rich countries for the period 1970-1995. After empirical analysis, these results also pointed out that government expenditure and EG have a negative relationship (10\% increase in government spending caused 0.7 to $0.8 \%$ decrease in EG) in rich countries because of large public sectors. Moreover, in this analysis other than OECD countries are also included and, in that case, taxation along with government spending is found to be negatively related to EG (Fölster \& Henrekson, 2001). Y1lmaz (2013) studied the effect of taxation in the presence of perfect market competition. Its modeling is comprised of three agents: household, firms, and government and firms function with three vertically integrated sectors: final goods sector (FGS), intermediate goods sector (IGS), and research sector (RS). Mathematical and theoretical demonstration of endogenous growth model (EGM) showed that in high competitive structure, chances of having the positive effect of an increase in taxation would be more, so it could be said both direct and indirect effects of competition are advantageous for the economy.

After reviewing the literature on tax structure and economic growth it becomes very clear that although voluminous work is done on this topic, but Asia countries are still not extensively studied. So, this comprehensive analysis will cover this gap and endow policymakers with a better understanding of tax structure affecting economic growth in the case of Asia and put off poor policy advice.

\section{Empirical Estimation and Data}

\subsection{Econometric Models} objective.

The following basic empirical model is specified to achieve our research

$$
G R_{i t}=\alpha+\beta G R_{i t-1}+\gamma X_{i t}+\mu_{i t}+\varepsilon_{i t}
$$

Here, GR is GDP growth rate, $\mathrm{X}$ consists of tax structure variables (Income taxation, corporate taxation, consumption taxation, etc), and other explanatory variables added in this research as considered as the determinants of GR. $\mu_{\text {it }}$ is the time-invariant country-specific effect and $\varepsilon$ it is an error term. 
In literature, a number of studies discuss the impact of taxes on growth; in some studies, simple correlation is observed and in other studies control for some additional growth determinants is done. Ferede and Dahlby (2019) and Hope (2019) included the level of investment as a control variable in their models. Di Sanzo et al. (2017), Adkisson and Mohammed (2014) added school enrolment ratios as a human capital proxy. Foreign direct investment and gross savings were used in the studies by Lee and Gordon (2005), Martinez-Vazquez et al. (2011), Gale and Perozek (2001). Furthermore, Ferede and Dahlby (2019), McNabb and LeMayBoucher (2015), Adkisson and Mohammed (2014), and Martinez-Vazquez et al. (2011) incorporated population growth and institutions as the components of their empirical modeling.

This model can be further specified as:

$$
\begin{aligned}
& G R_{i}=\beta_{0}+\beta_{i} G R_{i-1}+\beta_{i} \operatorname{DiTx}_{i}+\beta_{i} S S e_{i}+\beta_{i} G F c_{i}+\beta_{i} F \operatorname{Din}_{i}+\beta_{i} G S g_{i}+\beta_{i} \text { Popg }_{i}+\beta_{i} I N s t_{i}+\varepsilon_{i} \\
& G R_{i}=\beta_{0}+\beta_{i} G R_{i-1}+\beta_{i} I n d T x_{i}+\beta_{i} \operatorname{SSe}_{i}+\beta_{i} G F c_{i}+\beta_{i} F \operatorname{Din}_{i}+\beta_{i} G S g_{i}+\beta_{i} \text { Popg }_{i}+\beta_{i} I N s t_{i}+\varepsilon_{i} \\
& G R_{i}=\beta_{0}+\beta_{i} G R_{i-1}+\beta_{i} \operatorname{DiTx}_{i}+\beta_{i} \operatorname{IndTx}_{i}+\beta_{i} \operatorname{SSe}_{i}+\beta_{i} G F c_{i}+\beta_{i} \text { DDin }_{i}+\beta_{i} G S g_{i}+\beta_{i} \text { Popg }_{i}+\beta_{i} \text { INst }_{i}+\varepsilon_{i}
\end{aligned}
$$

Where GR = GDP-economic growth,

$\mathrm{GR}_{\mathrm{t}-1}=$ lag value of GDP,

DiTx $=$ direct taxes like corporate taxes, personal taxes, etc.

IndTx $=$ Indirect Taxes like sales taxes, trade taxes, etc.

$\mathrm{SSe}=$ Secondary school enrolment ratio

$\mathrm{GFc}=$ Gross fixed capital formation

FDin $=$ Foreign direct investment

$\mathrm{GSg}=$ Gross saving

Popg $=$ population growth rate

INst. $=$ Institutions

In the ICTD-GRD data set, tax values are expressed in the share of GDP.

\subsubsection{Control Variables}

Physical capital, human capital, trade, institutions, and population are considered as the basic growth determinants and are taken as control variables in this study by identifying its significance through literature. 


\section{Human Capital}

In this study, it is measured as a secondary school enrolment ratio. In literature, it has shown positive relation with economic growth as educated labor is beneficial especially for the survival from Economic depressions (Ogundari \& Awokuse, 2018; Artadi \& Sala-i-Martin, 2003; Kingdon, 2007; Self \& Grabowski, 2004; Kobzev Kotásková et al., 2018; Kyophilavong et al., 2018) and would have negative relation if education level is below threshold and country's total factor productivity declined (Benhabib \& Spiegel, 2005).

\section{Investment}

It is used as gross fixed capital formation in most cases it helps in enhancing growth so it affects economic growth positively (Gyimah-Brempong et al., 2006; Hossain \& Mitra, 2013; Khobai et al., 2016; Jangili, 2011; Kane et al., 2019). However sometimes long-term benefits of the investment may have a short-term decline or investment results may not be translated into growth in the period covered under study showing negatively affecting economic growth (Adkisson \& Mohammed, 2014; Ogundari \& Awokuse, 2018).

\section{Trade-Openness}

It is measured as a foreign direct investment; in previous literature, it has mixed findings. Sometimes directly affecting economic growth as liberalization policies are found encouraging (Gyimah-Brempong \& Wilson, 2004; Ogundari \& Awokuse, 2018; Adams \& Opoku, 2015; Khobai et al., 2016) and in other studies where the adequate institutional framework is missing, it has also shown inverse relation with economic growth (Busse \& Groizard, 2006; Bolaky \& Freund, 2004; Rodrik et al., 2004; Dollar \& Kraay, 2003).

\section{Government-Saving}

It is taken as gross saving as a percentage of GDP. In previous studies, twoway causality exists when it is taken as a source of capital stock that can be used for investment, employment, and construction that further can enhance economic growth, and one-way causality is found when there is a wide gap between saving and investment as in studies like Abu, (2010); Hailu, (2016); Sinha and Sinha (2008); Mohan, (2006); Rasmidatta, (2011); Verma et al. (2007). Insignificant or no relation at all is also observed in previous literature (Baharumshah et al., 2003).

\section{Population}

Annual population growth rate- mostly diminishes the available capital per worker so negatively affecting economic growth. 


\section{Institutions}

In this study principal component analysis (PCA) is used to construct a composite indicator of political and economic institutions and then to estimate their combined effect on EG. In the majority of studies institutions affect the economy positively (Flachaire et al., 2014; Faria et al., 2016; Sarwar et al., 2013; Glaeser et al., 2004; Acemoglu et al., 2019) but sometimes it does affect negatively especially when the institutional structure is incapable and corrupt.

\subsection{Data}

The main source of data set is ICTD by United Nation University (UNUWIDER) Government Revenue Dataset (GRD) for tax-related variables and ICRG (International Country Risk Guide), WDI (World Development Indicators) for other control variables. Data is collected from 1990 to 2017 for the panel of 20 middle-income Asian countries. This Income group categorization is selected by following World Bank classification and the GRD dataset has also incorporated this income-based division. Among Asia, middle-income countries are chosen because the purpose of this analysis is particularly to estimate the optimum tax structure for middle-income countries as they require more reforms to enhance their revenues and economic growth and this is also done to avoid missing data. The list of sample countries is shown in Appendix 1 (Table A1). We used the four-year averages data to smoothen it and to fulfill the requirements of our statistical techniques. Appendix 1 (Table A2) presents detail; definitions, abbreviations, sources, and descriptive statistics; of the dataset.

\section{Methodology}

Cross-sectional dependence may not be the issue in our data because mainly it is not a problem in micro panels with a large number of cross-sections and a small number of years but a matter of concern for macro panels with long time series (Baltagi, 2005). The presence of a lagged value of economic growth in the model shows the occurrence of correlation between the error term and regressors. Moreover, tax variables added in the analysis may not be perfectly exogenous and correlate with the error term generating the issue of endogeneity (Nickell, 1981; Roodman, 2009; Cornia et al., 2011). The presence of endogeneity restricts us to analyze OLS or FMOLS techniques (Abdallah et al., 2015; Baum \& Christopher, 2006). In this scenario, the preferred estimation technique seems to be the generalized method of moments. So, the two-step system GMM (Generalized Method of Moments) estimation technique is employed to overcome problems like endogeneity, autocorrelation, and heteroscedasticity (Claus et al., 2012). However, strength and validity of instruments are a matter of concern for the GMM technique, 
but this estimation is still considered helpful as a part of the whole portfolio of statistical tests (Yanikkaya \& Turan, 2020).

\subsection{Generalized Method of Moments}

GMM is introduced in 1982 by L. Hansen and further development in this estimation technique is made by Arellano and Bover, Arellano and Bond, Blundell and Bond, Rosen, Holtz-Eakin and Newey (Baum et al., 2003; Blundell \& Bond, 1998; Arellano \& Bover, 1995; Arellano \& Bond, 1991; Holtz-Eakin et al., 1988). GMM is a consistent estimation technique even in the existence of endogeneity, autocorrelation, and heteroscedasticity. GMM model which is appropriate for panel data estimation can be employed in the occurrence of three sources of endogeneity; simultaneity, dynamic endogeneity, and unobserved heterogeneity. The endogeneity issue is resolved in GMM by "internally changing the data" it is a statistical procedure where the lag value of the variable is added to the model (Roodman, 2009; Wooldridge, 2016; Wintoki et al., 2012). Difference and system GMM are two basic models and both are applicable for the situation where "large $\mathrm{N}$ and small T" holds is panel data meaning large individuals (cross-sections) and small-time periods. Dynamic panel GMM estimator uses the following moment conditions:

$\mathrm{E}\left[\Delta \mathrm{GR}_{\mathrm{it}-\mathrm{r}} \Delta \mu_{\mathrm{it}}\right]=0$ for all $\mathrm{r} \geq 2, \mathrm{t}=3 \ldots \ldots . \mathrm{T}$

$\mathrm{E}\left[\Delta \mathrm{X}_{\mathrm{it}-\mathrm{r}} \Delta \varepsilon_{\mathrm{it}}\right]=0$ for all $\mathrm{r} \geq 2, \mathrm{t}=3 \ldots \ldots \mathrm{T}$

It is the Difference GMM (d-GMM) that is based on these moment conditions. D-GMM is criticized based on biasness and imprecision. A familiar property of d-GMM is that in small samples standard error can be severely biased. One more basic weak point of d-GMM is that, specifically when series is persistent, for first difference lagged values of variables become weak instruments. While system GMM, based on additional assumptions, can overcome this issue of weak instruments. It employs both regressions together; level regression and first difference regression, which controls country heterogeneity, endogeneity, and omitted variable bias. So, the additional moment conditions are:

$$
\begin{aligned}
& \mathrm{E}\left[\Delta \mathrm{GR}_{\mathrm{it}-\mathrm{r}}\left(\mu_{\mathrm{it}}+\varepsilon_{\mathrm{it}}\right)\right]=0 \text { for } \mathrm{r}=1 \\
& \mathrm{E}\left[\Delta \mathrm{X}_{\mathrm{it}-\mathrm{r}}\left(\mu_{\mathrm{it}}+\varepsilon_{\mathrm{it}}\right)\right]=0 \text { for } \mathrm{r}=1
\end{aligned}
$$

The addition of these moments makes the system GMM more efficient, consistent, and popular in the empirical literature. Within system GMM there are 
two variants, one-step system GMM estimator and two-step system GMM estimator. The latter one is considered to be more efficient than the former one because it uses an optimal weighting matrix but in the case of small cross-sections, it may cause the standard error to give biased results and weaken the overidentification test. These issues lead to too many instruments and instrument proliferation and these issues can be resolved by reducing the dimensionality of the instrumental variable matrix (Windmeijer, 2005; Roodman, 2009). Hitherto, GMM estimation is a better alternative of fixed and random effect IV estimation, its estimators are wide enough to cover conventional estimators like GLS, ML, and IV estimators (Baum et al., 2003; Ahn, 1994). So in this analysis, we employ a twostep system GMM estimator to estimate the impact of tax structure variables on economic growth.

GMM estimator's consistency depends on three specification tests. First is a Sargan or Hensen test which is employed to check the validity of instruments; failure to reject the null hypothesis refers to the valid instruments in the model. Second is the difference-in-sargan/Hansen test of too many instruments in this case P-values in difference-in-Hansen tests show the validity of the additional moment restriction and again we fail to reject the null hypothesis states that the additional moment conditions are valid (Heid et al., 2012). Last is the autocorrelation test, Pvalues reported in the form of $\mathrm{AR}_{1}$ and $\mathrm{AR}_{2}$ represent the first and second-order autocorrelation of residuals and in this scenario, the absence of second-order autocorrelation should be rejected (Roodman, 2009; Baum et al., 2003).

\section{Results and Discussions}

Here we regress economic growth, direct and indirect taxes along with other explanatory variables with a two-step GMM estimation technique. Separate regressions are employed for various tax structure variables. Table-2 represents four models each covering a different component or combination of direct taxes and Table-3 presents five models for indirect taxes and Table- 4 is for three models of tax-mix. Positive and significant lagged dependent variables in all of these models validate the usage of dynamic panel estimation. The secondary school enrolment ratio (SSe) is insignificant in the majority of models (except models $7,9,10$ and 13 where it is negative), it means that in MI countries education level has not reached up to the level where it can positively affect economic growth as a factor of production. Similar results are found in Benhabib and Spiegel (2005). Further, we estimate that impact of investment $(\mathrm{GFc})$ on $\mathrm{EG}$ is positive in most of the cases, inferring the investment helps to boost EG in MI countries and this relation is found in the previous literature like Khobai et al. (2016); Jangili, (2011); 
Tax Structure and Economic Growth:

Middle-Income Asian Countries Analysis

Table 2: Dynamic panel-data estimation for Direct Taxation, two-step system-GMM

\begin{tabular}{|c|c|c|c|c|c|c|c|c|}
\hline \multirow{2}{*}{ Variables } & \multicolumn{2}{|c|}{ Model-1 } & \multicolumn{2}{|c|}{ Model-2 } & \multicolumn{2}{|c|}{ Model-3 } & \multicolumn{2}{|c|}{ Model-4 } \\
\hline & Co. & St. & Co. & St. & Co. & St. & Co. & St. \\
\hline lag_GR & $0.345^{* *}$ & 0.138 & $-0.218^{* *}$ & 0.102 & $0.394 * *$ & 0.144 & $-0.149 *$ & 0.107 \\
\hline $\mathrm{SSe}$ & -0.027 & 0.047 & -0.018 & 0.026 & 0.038 & 0.048 & -0.02 & 0.026 \\
\hline $\mathrm{GFc}$ & $0.758 * *$ & 0.278 & -0.038 & 0.129 & 0.701 & 0.425 & 0.074 & 0.197 \\
\hline FDin & -0.169 & 0.156 & $0.244 * *$ & 0.105 & -0.211 & 0.231 & $0.270^{*}$ & 0.142 \\
\hline GSg & -0.083 & 0.065 & $0.52 * * *$ & 0.123 & -0.143 & 0.135 & $0.557 * * *$ & 0.109 \\
\hline Popg & $-1.600 *$ & 0.775 & 0.836 & 0.624 & 0.084 & 0.333 & 0.649 & 0.594 \\
\hline INst. & $-4.21^{* *}$ & 1.916 & -0.597 & 0.597 & $-2.19 * * *$ & 0.388 & -0.899 & 0.604 \\
\hline DiTx & $-0.65^{* *}$ & 0.295 & & & & & & \\
\hline Tx-PiT & & & 0.171 & 0.435 & & & 0.284 & 0.382 \\
\hline Tx-CiT & & & $-0.866^{*}$ & 0.456 & & & $-1.124 * *$ & 0.457 \\
\hline TxPW & & & & & 23.877 & 46.682 & & \\
\hline $\operatorname{PrTx}$ & & & & & $-6.345^{* *}$ & 2.606 & 5.116 & 3.51 \\
\hline $\mathrm{AR}_{1}$ & $-2.15[0.031]$ & & $-1.20[0.229]$ & & $-2.09[0.037]$ & & $-1.34[0.180$ & \\
\hline $\mathrm{AR}_{2}$ & $0.71[0.476]$ & & $0.52[0.600]$ & & $0.35[0.728]$ & & $0.73[0.462]$ & \\
\hline Sargen Test & $14.39[0.156]$ & & $11.41[0.122]$ & & $9.87[0.361]$ & & $9.02[0.251]$ & \\
\hline $\begin{array}{l}\text { Difference-in- } \\
\text { Hansen Test }\end{array}$ & $11.10[0.196]$ & & $7.37[0.195]$ & & $7.10[0.418]$ & & $8.85[0.115]$ & \\
\hline $\begin{array}{l}\text { No. of } \\
\text { instruments }\end{array}$ & 19 & & 17 & & 19 & & 18 & \\
\hline No. of groups & 20 & & 20 & & 20 & & 20 & \\
\hline $\begin{array}{l}\text { Note: } 1 . \text { lag } \\
\text { foreign dire } \\
=\text { total taxes } \\
\text { taxes; TxPy } \\
\text { 4. Level of }\end{array}$ & $\begin{array}{l}\mathrm{GR}=\text { lag econ } \\
\text { t investment; } \mathrm{C} \\
\text { on income pro } \\
\text { = payroll \& w } \\
\text { ignificance is } \mathrm{r}\end{array}$ & $\begin{array}{l}\text { omic gro } \\
\mathrm{Sg}=\text { gro } \\
\text { it \& capi } \\
\text { rkforce } \mathrm{t} \\
\text { presente }\end{array}$ & $\begin{array}{l}\mathrm{SSe}=\text { seconda } \\
\text { ving; Popg = p } \\
\text { ins; Tx-PiT = } \\
\text { 2. Values in br } \\
* * \text { p }<0.01, * * 1\end{array}$ & $\begin{array}{l}\text { school e } \\
\text { ulation g } \\
\text { rsonal in } \\
\text { kets are P } \\
<0.05, * \mathrm{p}\end{array}$ & $\begin{array}{l}\text { Iment; } \mathrm{GFc}=\mathrm{g} \\
\text { th; INst. = inst } \\
\text { e taxes; } \mathrm{Tx}^{-} \mathrm{Ci}^{\prime} \\
\text { lues. } 3 . \mathrm{AR}_{1} \text { an } \\
\text { 1. }\end{array}$ & $\begin{array}{l}\text { oss fixed } \\
\text { utions; } \mathrm{Di}^{\prime} \\
=\text { corpora } \\
\mathrm{AR}_{2} \text { are } \mathrm{s}\end{array}$ & $\begin{array}{l}\text { ital formation; } \\
=\text { direct taxes; } \\
\text { axes; PrTx = } \\
1 \text { autocorrelati }\end{array}$ & $\begin{array}{l}\text { Din = } \\
\text { KIpcT } \\
\text { perty } \\
\text { tests. }\end{array}$ \\
\hline $\begin{array}{l}\text { Kane et } \\
\text { are mix } \\
\text { negative } \\
\text { tax syst } \\
\text { Busse a } \\
\text { modelin } \\
\text { directly } \\
\text { econom } \\
2006 ; \mathrm{J}\end{array}$ & $\begin{array}{l}\text { al. (2019) } \\
\text { ed in MI c } \\
\text { and in ott } \\
\text { ems in dif } \\
\text { nd Groiza } \\
\text { g to check } \\
\text { affecting } \\
\text { y of MI A } \\
\text { gadeesh, }\end{array}$ & $\begin{array}{l}\text { Hoss } \\
\text { untri } \\
\text { ers it } \\
\text { erent } \\
\text { d ( } 20 \\
\text { the in } \\
\text { conor } \\
\text { sian ce } \\
2015) \text {. }\end{array}$ & $\begin{array}{l}\text { and Mitra } \\
\text { x structur } \\
\text { isignifica } \\
\text { es trade r } \\
\text { Paparas } \\
\text { t of savin } \\
\text { growth. S } \\
\text { ries (Moh } \\
\text { oulation }\end{array}$ & $\begin{array}{l}2013 \\
\text { analy } \\
\text { shor } \\
\text { ults a } \\
\text { al. ( } \\
\text { on E } \\
\text { savi } \\
\text { nty, } 2 \\
\text { opg) }\end{array}$ & $\begin{array}{l}\text { Findings } \\
\text { s; in some } \\
\text { ag that in } \\
0 \text { vary } \mathrm{Ad} \\
15) \text {. GSg } \\
\text { and in the } \\
\text { can be cc } \\
9 \text {; Sajid } 8 \\
\text { mains insi }\end{array}$ & $\begin{array}{l}\text { trade } \\
\text { models } \\
\text { he pres } \\
\text { ims an } \\
\text { is also } \\
\text { najorit } \\
\text { asidere } \\
\text { Sarfra } \\
\text { nificar }\end{array}$ & $\begin{array}{l}\text { tenness ( } \\
\text { is positi } \\
\text { Opoku }(2 \\
\text { acluded i } \\
\text { of models } \\
\text { fruitful fo } \\
\text { 2008; M } \\
\text { (Sarwar }\end{array}$ & $\begin{array}{l}\text { Din) } \\
\text { e or } \\
\text { rent } \\
15) \text {; } \\
\text { our } \\
\text { it is } \\
\text { the } \\
\text { lan, } \\
\text { al., }\end{array}$ \\
\hline
\end{tabular}


2013) and the negative coefficient of institutions (INst.) implies that the poorly developed institutions are incapable of stimulating economic growth in MI Asian countries (Kane et al., 2019).

Diagnostic tests' results in all models are also well specified. The number of instruments is not greater than the number of cross-sections so there will be no issue of too many instruments in the models. The null hypothesis of $1^{\text {st }}$ and $2^{\text {nd }}$ order correlation is failed to reject and Sargan \& Difference-in-Hansen Test also fails to reject the null hypothesis in all models; showing that instruments are valid.

The negative and significant coefficient of direct taxation demonstrates that with one unit increase in direct taxes economic growth declines by about 0.65 units (Adam \& Opoku, 2015; Khobai et al., 2016). For middle-income Asian countries, direct taxes are not seen to be productive for economic growth even if these are in the form of corporate or property taxes because these have a harmful impact on labor productivity, labor utilization, total factor productivity, and hence economic growth. In almost all the models of corporate income taxes, these are showing a negative impact on economic growth (model-2 \& 4); one unit increase in corporate taxation can decrease economic growth from 0.86 to 1.12 units. Income taxes are perceived here as damaging to economic growth it might be because these are progressive taxes and their marginal rates are higher than average rates that would ultimately discourage further growth and would also induce low wage laborers to stay on social benefits rather than to do work. Corporate taxes are particularly dangerous as they discourage a firm's activities and also dampen the small \& medium size firms financial capabilities that are inevitable for economic growth (Ferede \& Dahlby, 2019; Gale et al., 2015; McNabb \& LeMay-Boucher, 2015; Dahlby \& Ferede, 2012; Djankov et al., 2010; Szarowska, 2010; Lee \& Gordon, 2005). However, personal income taxes and payroll \& workforce taxes remain insignificant. Findings of all autocorrelation tests, Sargen test, and difference-inHansen test show in all models that all instruments are valid and there is no issue of $2^{\text {nd }}$ order correlation.

In MI Asian countries analysis, overall indirect taxes are proved to be fruitful for economic growth. One unit increase in indirect taxation can cause economic growth of about 0.639 units. The combined effect of goods \& services taxes is also positive. It is because indirect taxes although increase the price of consumer goods and somehow also affect labor supply but they do not suppress investment and saving especially if the rate is expected to be constant over time. The marginal consumption tax rate is also found to have a positive effect on private investment in the literature. However, when Gst and Vat are levied together then 
Gst entails positive and Vat brings about a negative change in economic growth (Stoilova, 2017; Ormaechea \& Yoo, 2012; Dahlby \& Ferede, 2012). The negative coefficient of international trade taxes also shows its harmful effect on the economy as it increases the costs of many imported inputs and makes import-based business difficult to operate and expensive for the industries. One unit increase in international trade duties can decline the economic growth ranging from 0.645 to

Table 3: Dynamic panel-data estimation for Indirect Taxation, two-step system GMM

\begin{tabular}{|c|c|c|c|c|c|c|c|c|c|c|}
\hline \multirow{2}{*}{ Variables } & \multicolumn{2}{|c|}{ Model-5 } & \multicolumn{2}{|c|}{ Model-6 } & \multicolumn{2}{|c|}{ Model-7 } & \multicolumn{2}{|c|}{ Model-8 } & \multicolumn{2}{|c|}{ Model-9 } \\
\hline & Co. & St. & Co. & St. & Co. & St. & Co. & St. & Co. & St. \\
\hline lag_GR & $0.276^{* * *}$ & 0.073 & $0.222^{*}$ & 0.118 & 0.29 & 0.184 & $0.195^{*}$ & 0.105 & $0.223^{* *}$ & 0.093 \\
\hline $\mathrm{SSe}$ & 0.01 & 0.034 & $-0.14 * * *$ & 0.046 & -0.069 & 0.084 & $-0.05 * * *$ & 0.016 & $-0.15 * * *$ & 0.046 \\
\hline $\mathrm{GFc}$ & $0.297 * *$ & 0.118 & $0.726 * * *$ & 0.179 & $0.966^{*}$ & 0.518 & $0.464 * *$ & 0.215 & 0.749 *** & 0.256 \\
\hline FDin & -0.041 & 0.089 & $-0.195^{*}$ & 0.095 & -0.164 & 0.259 & -0.011 & 0.129 & $-0.236^{*}$ & 0.12 \\
\hline GSg & $0.059^{*}$ & 0.049 & -0.075 & 0.069 & -0.176 & 0.11 & -0.033 & 0.057 & -0.018 & 0.096 \\
\hline Popg & -0.503 & 0.325 & -0.476 & 0.887 & $-1.779 * *$ & 0.634 & -0.445 & 0.518 & -0.105 & 0.767 \\
\hline INst. & -0.507 & 1.405 & $-5.16^{* * * *}$ & 1.389 & $-4.175^{* *}$ & 1.802 & -1.067 & 0.76 & $-4.28 * * *$ & 1.387 \\
\hline IndTx & $0.639 * *$ & 0.236 & & & & & & & & \\
\hline TxGsT & & & $0.644 *$ & 0.334 & & & & & 0.312 & 0.388 \\
\hline Gst & & & & & $1.231 *$ & 0.699 & & & & \\
\hline Vat & & & & & $-2.82 * * *$ & 0.757 & & & & \\
\hline TxInt. & & & & & & & $-0.654^{*}$ & 0.332 & $-1.603^{*}$ & 0.783 \\
\hline OthTx & & & & & & & & & $2.559 * *$ & 1.018 \\
\hline $\mathrm{AR}_{1}$ & \multicolumn{2}{|c|}{$-2.34[0.019]$} & \multicolumn{2}{|c|}{$-1.42[0.156]$} & \multicolumn{2}{|c|}{$-1.38[0.167]$} & \multicolumn{2}{|c|}{$-1.82[0.069]$} & \multicolumn{2}{|c|}{$-2.38[0.017]$} \\
\hline $\mathrm{AR}_{2}$ & \multicolumn{2}{|c|}{$0.83[0.406]$} & \multicolumn{2}{|c|}{$-0.07[0.941]$} & \multicolumn{2}{|c|}{$0.02[0.980]$} & \multicolumn{2}{|c|}{$0.61[0.541]$} & \multicolumn{2}{|c|}{$-0.49[0.624]$} \\
\hline Sargen Test & \multicolumn{2}{|c|}{$10.04[0.347]$} & \multicolumn{2}{|c|}{$4.66[0.793]$} & \multicolumn{2}{|c|}{$9.48[0.303]$} & \multicolumn{2}{|c|}{$10.49[0.312]$} & \multicolumn{2}{|c|}{6.19 [0.939] } \\
\hline $\begin{array}{l}\text { Difference-in- } \\
\text { Hansen Test }\end{array}$ & \multicolumn{2}{|c|}{$11.34[0.125]$} & \multicolumn{2}{|c|}{$4.83[0.566]$} & \multicolumn{2}{|c|}{$11.37[0.708]$} & \multicolumn{2}{|c|}{$5.94[0.547]$} & \multicolumn{2}{|c|}{$6.57[0.765]$} \\
\hline $\begin{array}{l}\text { No. of } \\
\text { instruments }\end{array}$ & \multicolumn{2}{|l|}{18} & \multicolumn{2}{|c|}{17} & \multicolumn{2}{|c|}{18} & \multicolumn{2}{|c|}{18} & \multicolumn{2}{|c|}{19} \\
\hline No. of groups & \multicolumn{2}{|l|}{20} & \multicolumn{2}{|c|}{20} & 20 & & 20 & & 20 & \\
\hline
\end{tabular}

Note: 1. lag_GR = lag economic growth; SSe = secondary school enrolment; GFc = gross fixed capital formation; FDin = foreign direct investment; GSg = gross saving; Popg = population growth; INst. =institutions; TxIpcT = total taxes on income profit \& capital gains; Tx-PiT = personal income taxes; Tx-CiT = corporate taxes; PrTx =property taxes; IndTx = indirect taxes; TxGsT = total taxes on goods \& services; Gst = general sale taxes; Vat = value added taxes; TxInt. = international trade taxes; OthTx $=$ other taxes. 2. Values in brakets are P-values. 3. $\mathrm{AR}_{1}$ and $\mathrm{AR}_{2}$ are serial autocorrelation tests. 4. Level of significance is represented as $* * * \mathrm{p}<0.01, * * \mathrm{p}<0.05, * \mathrm{p}<0.1$. 
Table 4: Dynamic panel-data estimation for Tax Mix, two-step system GMM

\begin{tabular}{|c|c|c|c|c|c|c|}
\hline \multirow[t]{2}{*}{ Variables } & \multicolumn{2}{|l|}{ Model-11 } & \multicolumn{2}{|l|}{ Model-12 } & \multicolumn{2}{|l|}{ Model-13 } \\
\hline & Co. & St. & Co. & St. & Co. & St. \\
\hline lag_GR & $0.266^{* *}$ & 0.123 & -0.111 & 0.235 & $0.217^{* *}$ & 0.076 \\
\hline $\mathrm{SSe}$ & -0.017 & 0.04 & -0.063 & 0.045 & $-0.101 * *$ & 0.046 \\
\hline $\mathrm{GFc}$ & $0.527 * *$ & 0.246 & 0.207 & 0.256 & 0.044 & 0.216 \\
\hline FDin & 0.023 & 0.178 & 0.046 & 0.176 & 0.144 & 0.111 \\
\hline GSg & $0.159^{*}$ & 0.089 & $0.621 * * *$ & 0.143 & $0.280 * * *$ & 0.08 \\
\hline Popg & -0.249 & 0.534 & 0.84 & 0.5 & $-1.897 * *$ & 0.72 \\
\hline INst. & $-2.400 * * *$ & 0.798 & $-2.032 * *$ & 0.868 & 0.047 & 1.318 \\
\hline DiTx & $-0.916 * *$ & 0.418 & & & & \\
\hline TxIpcT & & & $-1.274 * * *$ & 0.306 & & \\
\hline Tx-PiT & & & & & -1.525 & 1.393 \\
\hline Tx-CiT & & & & & 0.251 & 0.571 \\
\hline IndTx & $0.917 * *$ & 0.413 & & & & \\
\hline TxGsT & & & $1.038^{* * *}$ & 0.406 & & \\
\hline Gst & & & & & $4.051^{* * * *}$ & 1.257 \\
\hline Vat & & & & & $-2.773 * * *$ & 0.829 \\
\hline $\mathrm{AR}_{1}$ & $-1.32[0.186]$ & & $-1.00[0.316]$ & & $-1.28[0.202]$ & \\
\hline $\mathrm{AR}_{2}$ & $0.44[0.657]$ & & $0.44[0.659]$ & & $1.14[0.254]$ & \\
\hline Sargen Test & $5.20[0.635]$ & & $2.90[0.894]$ & & $16.94[0.202]$ & \\
\hline Difference-in-Hansen Test & $6.05[0.302]$ & & $5.54[0.354]$ & & $12.30[0.266]$ & \\
\hline Number of instruments & 17 & & 17 & & 17 & \\
\hline Number of groups & 20 & & 20 & & 20 & \\
\hline $\begin{array}{l}\text { Note: } 1 . \text { lag_GR = lag econ } \\
\text { foreign direct investment; } \\
\text { profit \& capital gains; Tx-P } \\
\text { taxes; TxGsT = total taxes } \\
\text { trade taxes; OthTx = other t } \\
\text { of significance is represente }\end{array}$ & $\begin{array}{l}\text { th; } \mathrm{SSe}=\mathrm{sec} \\
\text { saving; Popg } \\
\text { nal income ta } \\
\text { \& services; Gs } \\
\text { lues in braket } \\
<0.01, * * \mathrm{p}<0\end{array}$ & $\begin{array}{l}\text { lary sch } \\
\text { opulatic } \\
; \text { Tx-C } \\
\text { genera } \\
\text { e P-val } \\
* \text { p }<0\end{array}$ & $\begin{array}{l}\text { enrolment; G } \\
\text { owth; INst. =i } \\
\text { corporate tax } \\
\text { e taxes; Vat }= \\
\text { 3. } \mathrm{AR}_{1} \text { and A }\end{array}$ & $\begin{array}{l}=\text { gross fi } \\
\text { tutions; } \\
\text { PrTx =pr } \\
\text { lue adde } \\
\text { are serial }\end{array}$ & $\begin{array}{l}\text { capital format } \\
\text { pcT = total taxe } \\
\text { erty taxes; IndT } \\
\text { xes; TxInt. = i } \\
\text { tocorrelation te }\end{array}$ & $\begin{array}{l}\mathrm{n} ; \text { FDin }= \\
\text { on income } \\
=\text { indirect } \\
\text { ernational } \\
\text { 4. Level }\end{array}$ \\
\hline
\end{tabular}

1.603. All other taxes have a direct impact on economic growth (McNabb \& LeMay-Boucher, 2015). All instruments are valid as is indicated in the diagnostics tests.

Different and quite astonishing results are observed in the case of the tax mix when both direct and indirect taxes are levied together at the same time. Tax mix analysis shows that the positive impact of indirect taxes can overcome the 
negative effect of direct taxes if both are charged together. In the same way in model-12 we can observe that the coefficient of total taxes on income profit \& capital gains is negative while on the other side coefficient of total taxes on goods $\&$ services is almost the same in weight but positive in sign. When income and consumption taxes are divided into their component taxes we will see that personal income and corporate income taxation become insignificant and coefficient of Gst remain positive and significant, showing that shifting to consumption tax from income tax can be beneficial for the economies of MI Asian countries. As some taxes which are considered harmful for the economy previously have become positive or remain insignificant now when charged along with other taxes. It means that charging taxation can be fruitful for the economies if enough thinking is given to the tax structure. The same kind of results are also found in Yanikkaya and Turan (2020); Acosta-Ormaechea et al. (2019); McNabb and LeMay-Boucher (2015); Wenli and Sarte (2004); Widmalm (2001).

\section{Concluding Remarks}

This paper estimates the relationship between economic growth and tax structure using data of 20 middle-income Asian countries for 1990-2017 by using a quite novel and wide-range dataset of WIDE-GRE. The contribution of this paper in tax structure literature is that it conducts a detailed analysis considering both direct and indirect taxes of middle-income Asian countries. Tax structure being a broad concept is divided into direct and indirect taxes that are further separated into their component taxes to estimate the separate and combined effect of different taxes on economic growth. This research work employs a dynamic approach method, the Systematic Generalized Method of Moments (GMM). By finding a considerable impact of tax structure on long term economic growth in MI Asian countries, suggests some important policy implications to the governments to adjust tax structure for economic growth. In a separate analysis, empirical findings show that direct taxes are not good to foster economic growth particularly corporate taxes are detrimental whether charged alone or along with other direct taxes. Overall indirect taxes are found to be positively affecting economies in MI Asian countries; in these Gst and other taxes are proved to be supportive but international trade taxes have somehow declining effect on the economic growth. Combine analysis of direct and indirect taxes, tax mix, shows that taxes on goods \& services and general sale taxes are favorable while taxes on income profit $\&$ capital gains are damaging for the growth. Moreover, the positive effect of indirect taxes can outweigh the negative effect of direct taxes if direct and indirect taxes are levied together. This might be because the tax base in the case of consumption taxes is broader than the direct taxes as consumption needs are financed even by means other than wages. It 
means that moving to consumption taxes can be supportive of middle-income Asian countries. Hence, the findings of this analysis have the noteworthy potential for policymakers of middle-income Asian countries that is to choose an efficient tax structure design to optimize economic growth and then development. 


\section{References}

Abdallah, W., Goergen, M., \& O'Sullivan, N. (2015). Endogeneity: How failure to correct for it can cause wrong inferences and some remedies. British Journal of Management, 26(4), 791-804.

Abu, N. (2010). Saving-economic growth nexus in Nigeria, 1970-2007: Granger causality and co-integration analyses. Review of Economic and Business Studies, 5, 93-104.

Acemoglu, D., Naidu, S., Restrepo, P., \& Robinson, J. A. (2019). Democracy does cause growth. Journal of Political Economy, 127(1), 47-100.

Acosta-Ormaechea, S., Sola, S., \& Yoo, J. (2019). Tax composition and growth: A broad cross country perspective. German Economic Review, 20(4), 70-106.

Adams, S., \& Opoku, E. E. O. (2015). Foreign direct investment, regulations and growth in sub-Saharan Africa. Economic Analysis and Policy, 47, 48-56.

Adkisson, R. V., \& Mohammed, M. (2014). Tax structure and state economic growth during the Great Recession. The Social Science Journal, 51(1), 7989.

Agell, J., Ohlsson, H., \& Thoursie, P. S. (2006). Growth effects of government expenditure and taxation in rich countries: A comment. European Economic Review, 50(1), 211-218.

Ahn, S. (1994). Robust GMM tests for model specification, with applications to conditional moments testing and structural instability testing. Mimeo, Arizona State University.

Ali, M., Fjeldstad, O. H., \& Sjursen, I. H. (2014). To pay or not to pay? Citizens' attitudes toward taxation in Kenya, Tanzania, Uganda, and South Africa. World Development, 64, 828-842.

Amoah, G. M. (2014). The drivers of tax revenues in transition economies: Evidence from Ghana: 1980 to 2011 (Doctoral dissertation). University of Phoenix.

Arellano, M., \& Bond, S. (1991). Some tests of specification for panel data: Monte Carlo evidence and an application to employment equations. The Review of Economic Studies, 58(2), 277-297. 
Arellano, M., \& Bover, O. (1995). Another look at the instrumental variable estimation of error components models. Journal of Econometrics, 68(1), 2951 .

Arnold, J. M., Brys, B., Heady, C., Johansson, Å., Schwellnus, C., \& Vartia, L. (2011). Tax policy for economic recovery and growth. The Economic Journal, 121(550), 59-80.

Artadi, E. V., \& Sala-i-Martin, X. (2003). The economic tragedy of the XXth century: Growth in Africa. National Bureau of Economic Research, Working Paper, 9865.

Atems, B. (2015). Another look at tax policy and state economic growth: The longrun and short run of it. Economics Letters, 127, 64-67.

Baharumshah, A. Z., Thanoon, M. A., \& Rashid, S. (2003). Saving dynamics in the Asian countries. Journal of Asian Economics, 13(6), 827-845.

Bakari, S. (2018). If France continues this strategy, taxes will destroy domestic investment and economic growth. University Library of Munich, Germany, Munich Personal Repec Archive Paper, 88944.

Baltagi, B. H. (2005). Econometric analysis of panel data (Third Edition). New York, Wiley.

Barro, R. J. (1990). Government spending in a simple model of endogenous growth. Journal of Political Economy, 98(5), 103-125.

Barro, R. J. (1991). Economic growth in a cross section of countries. The Quarterly Journal of Economics, 106(2), 407-443.

Baum, C. F., \& Christopher, F. (2006). An introduction to modern econometrics using Stata. Stata press.

Baum, C. F., Schaffer, M. E., \& Stillman, S. (2003). Instrumental variables and GMM: Estimation and testing. The Stata Journal, 3(1), 1-31.

Benhabib, J., \& Spiegel, M. M. (2005). Human capital and technology diffusion. Handbook of Economic Growth, 1, 935-966.

Bird, R. M., Martinez-Vazquez, J., \& Torgler, B. (2008). Tax effort in developing countries and high income countries: The impact of corruption, voice and accountability. Economic Analysis and Policy, 38(1), 55-71.

Blundell, R., \& Bond, S. (1998). Initial conditions and moment restrictions in dynamic panel data models. Journal of Econometrics, 87(1), 115-143. 
Bolaky, B., \& Freund, C. (2004). Trade, regulations, and growth. World Bank, Working Paper ,3255.

Bujang, I., Hakim, T. A., \& Ahmad, I. (2013). Tax structure and economic indicators in developing and high income OECD countries: Panel cointegration analysis. Procedia Economics and Finance, 7, 164-173.

Busse, M., \& Groizard, J. L. (2006). Foreign direct investment, regulations, and growth.World Bank, Working Paper, 3882.

Cassou, S. P. (1997). The link between tax rates and foreign direct investment. Applied Economics, 29(10), 1295-1301.

Castro, G. Á., \& Camarillo, D. B. R. (2014). Determinants of tax revenue in OECD countries over the period 2001-2011. Contaduría y Administración, 59(3), $35-59$.

Chaudhry, I. S., \& Munir, F. (2010). Determinants of low tax revenue in Pakistan. Pakistan Journal of Social Sciences, 30(2), 439-452.

Claus, I., Martinez-Vazquez, J., \& Vulovic, V. (2012). Government fiscal policies and redistribution in Asian countries. Inequality in Asia and the Pacific, 173201.

Cornia, G. A., Gomez-Sabaini, J. C., \& Martorano, B. (2011). A new fiscal pact, tax policy changes and income inequality: Latin America during the last decade. Econstar, Working Paper, 2011/70.

Dahlby, E. F. B., \& Ferede, E. (2012). The impact of tax cuts on economic growth: Evidence from the Canadian provinces. National Tax Journal, 65(3), 563594.

Di Sanzo, S., Bella, M., \& Graziano, G. (2017). Tax structure and economic growth: A panel cointegrated VAR analysis. Italian Economic Journal, 3(2), 239-253.

Dioda, L. (2012). Structural determinants of tax revenue in Latin America and the Caribbean, 1990-2009. Economic Commision for Latin America and Caribbean.

Djankov, S., Ganser, T., McLiesh, C., Ramalho, R., \& Shleifer, A. (2010). The effect of corporate taxes on investment and entrepreneurship. American Economic Journal: Macroeconomics, 2(3), 31-64. 
Dollar, D., \& Kraay, A. (2003). Institutions, trade, and growth. Journal of Monetary Economics, 50(1), 133-162.

Faria, H. J., Montesinos, Y. H. M., Morales, D. R., \& Navarro, C. E. (2016). Unbundling the roles of human capital and institutions in economic development. European Journal of Political Economy, 45, 108-128.

Ferede, E., \& Dahlby, B. (2019). The effect of corporate income tax on the economic growth rates of the Canadian provinces. The School of Public Policy Publications, Available at: https://ssrn.com/abstract=3472384

Flachaire, E., García-Peñalosa, C., \& Konte, M. (2014). Political versus economic institutions in the growth process. Journal of Comparative Economics, 42(1), 212-229.

Fölster, S., \& Henrekson, M. (2001). Growth effects of government expenditure and taxation in rich countries. European Economic Review, 45(8), 15011520.

Gale, W. G., \& Perozek, M. G. (2001). Do estate taxes reduce saving? Rethinking Estate and Gift Taxation, 216-218.

Gale, W. G., Krupkin, A., \& Rueben, K. S. (2015). The relationship between taxes and growth at the state level: New evidence. National Tax Journal, 68(4), Available at: https://ssrn.com/abstract $=3385496$

Glaeser, E. L., La Porta, R., Lopez-de-Silanes, F., \& Shleifer, A. (2004). Do institutions cause growth? Journal of Economic Growth, 9(3), 271-303.

Grdinić, M., Drezgić, S., \& Stanković, J. (2017, January). Tax structure and economic growth recommendations and reforms in CEE countries. In Economic and Social Development 23rd International Scientific Conference on Economic and Social Development, University North, Croatia.

Gupta, A. S. (2007). Determinants of tax revenue efforts in developing countries. International Monetary Fund, Working Paper, 07/184.

Gyimah-Brempong, K., \& Wilson, M. (2004). Health human capital and economic growth in Sub-Saharan African and OECD countries. The Quarterly Review of Economics and Finance, 44(2), 296-320.

Gyimah-Brempong, K., Paddison, O., \& Mitiku, W. (2006). Higher education and economic growth in Africa. The Journal of Development Studies, 42(3), 509529. 
Hailu, A. M. (2016). The Relationship between National Saving and Economic Growth in Ethiopia: ARDL and Granger causality Approaches (Doctoral dissertation). Addis Ababa University Addis Ababa, Ethiopia.

Heid, B., Langer, J., \& Larch, M. (2012). Income and democracy: Evidence from system GMM estimates. Economics Letters, 116(2), 166-169.

Holtz-Eakin, D., Newey, W., \& Rosen, H. S. (1988). Estimating vector autoregressions with panel data. Econometrica, 56(6),1371-1395.

Hope, A. D. (2019). Tax Structure and Economic Growth in Ghana (Doctoral dissertation). University of Ghana.

Hossain, M. S., \& Mitra, R. (2013). The determinants of economic growth in Africa: A dynamic causality and panel cointegration analysis. Economic Analysis and Policy, 43(2), 217.

International Centre for Tax and Development. (2020). Government revenue dataset. Retrieved from

https://www.wider.unu.edu/project/government-revenue-dataset

World Bank. (2020). World development indicators. Retrieved from https://databank.worldbank.org/source/world-development-indicators

Islam, M. R. (2016). Contribution of indirect taxes on GDP of Bangladesh. Asia Pacific Journal of Research, 1(38), 213-217.

Jagadeesh, D. (2015). The impact of savings in economic growth: An empirical study based on Botswana. International Journal of Research in Business Studies and Management, 2, 10-21.

Jangili, R. (2011). Causal relationship between saving, investment and economic growth for India, what does the relation imply? Reserve Bank of India Occasional Papers , 32(1), 25-39.

Juliana, M. I. (2018). Effect of tax structure on economic growth in Nigeria. International Journal of Innovative Finance and Economics Research, 6(1), 1-11.

Kane, C. S., Thérèse, E. Z., \& Diandy, I. Y. (2019). Institutions and the economic performance of Central African Countries. Theoretical Economics Letters, 9(1), 33-49.

Karagöz, K. (2013). Determinants of tax revenue: does sectorial composition matter? Journal of Finance, Accounting \& Management, 4(2), 50-63. 
Karimi, M., Kaliappan, S. R., Ismail, N. W., \& Hamzah, H. Z. (2016). The impact of trade liberalization on tax structure in developing countries. Procedia Economics and Finance, 36, 274-282.

Katsios, S. (2006). The shadow economy and corruption in Greece, South Eastern Europe. Journal of Economics, 1, 61-80.

Khobai, H., Abel, S., \& Le Roux, P. (2016). Co-integration between electricity supply and economic growth in South Africa. International Journal of Energy Economics and Policy, 6(3), 637-645.

Kingdon, G. G. (2007). The progress of school education in India. Oxford Review of Economic Policy, 23(2), 168-195.

Kobzev Kotásková, S., Procházka, P., Smutka, L., Maitah, M., Kuzmenko, E., Kopecká, M., \& Hönig, V. (2018). The impact of education on economic growth: The case of India. Acta Universitatis Agriculturae Et Silviculturae Mendelianae Brunensis, 66(1), 253-262.

Kyophilavong, P., Ogawa, K., Kim, B., \& Nouansavanh, K. (2018). Does education promote economic growth in Lao PDR? Evidence from Cointegration and Granger causality approaches. The Journal of Developing Areas, 52(2), 111 .

Le, T. M., Moreno-Dodson, B., \& Bayraktar, N. (2012). Tax capacity and tax effort: Extended cross country analysis from 1994 to 2009. World Bank, Working Paper, Available at : https://doi.org/10.1596/1813-9450-6252

Lee, Y., \& Gordon, R. H. (2005). Tax structure and economic growth. Journal of Public Economics, 89(5), 1027-1043.

Levine, R., \& Renelt, D. (1992). A sensitivity analysis of cross country growth regressions. The American Economic Review, 82(4), 942-963.

Martinez-Vazquez, J. (2014). Taxation in Asia. Asian Development Bank.

Martinez-Vazquez, J., Vulovic, V., \& Liu, Y. (2011). Direct versus indirect taxation: trends, theory, and economic significance. In the Elgar guide to tax systems, Edward Elgar Publishing, Avialbe at : https://doi.org/10.4337/9780857933898

McNabb, K., \& LeMay-Boucher, P. (2015). Tax structures, economic growth and development. International Center for Tax and Development, Working Paper 22, Available at: http://dx.doi.org/10.2139/ssrn.2496470 
Mohan, R. (2006). Causal relationship between savings and economic growth in countries with different income levels. Economics Bulletin, 5(3), 1-12.

Mohanty, A. K. (2019). Does domestic saving cause economic growth? Time series evidence from Ethiopia. International Journal of Management, IT and Engineering, 7(10), 237-262.

Moore, M., \& Schneider, A. (2004). Taxation, governance and poverty: where do the middle-income countries fit? Institute of Development Studies, Working Paper,230, Available at: https://opendocs.ids.ac.uk/opendocs/handle/20.500.12413/4069

Neog, Y., \& Gaur, A. K. (2020). Tax structure and economic growth in India: Insights from ARDL model. Indian Growth and Development Review, 13(3), 589-605.

Nickell, S. (1981). Biases in dynamic models with fixed effects. Econometrica, 49(6), 1417-1426.

Ogundari, K., \& Awokuse, T. (2018). Human capital contribution to economic growth in Sub-Saharan Africa: Does health status matter more than education? Economic Analysis and Policy, 58, 131-140.

Ojede, A., \& Yamarik, S. (2012). Tax policy and state economic growth: The longrun and short-run of it. Economics Letters, 116(2), 161-165.

Ojong, C. M., Anthony, O., \& Arikpo, O. F. (2016). The impact of tax revenue on economic growth: Evidence from Nigeria. Journal of Economics and Finance , 7(1), 32-38.

Ormaechea, M. S. A., \& Yoo, M. J. (2012). Tax composition and growth: A broad cross country perspective. International Monetary Fund, Working Paper, $12-257$.

Paparas, D., Richter, C., \& Paparas, A. (2015). Fiscal policy and economic growth, empirical evidence in European Union. Turkish Economic Review, 2(4), 239-268.

Pessino, C. and Fenochietto, R. (2010). Determining countries' tax effort. Revista de Economía Pública, 195 (4), 65-87.

Piancastelli, M. (2001). Measuring the tax effort of developed and developing countries: Cross country panel data analysis 1985/95. Institute of Applied Economic Research, Brasília, Working Paper, 818. 
Prichard, W. (2016). Reassessing tax and development research: a new dataset, new findings, and lessons for research. World Development, 80, 48-60.

Rasmidatta, P. (2011). The relationship between domestic saving and economic growth and convergence hypothesis: case study of Thailand (Master Thesis). Södertörn University College, School of Social Sciences.

Rodrik, D., Subramanian, A., \& Trebbi, F. (2004). Institutions rule: the primacy of institutions over geography and integration in economic development. Journal of Economic Growth, 9(2), 131-165.

Roodman, D. (2009). How to do xtabond2: An introduction to difference and system GMM in Stata. The stata journal, 9(1), 86-136.

Sajid, G. M., \& Sarfraz, M. (2008). Savings and economic growth in Pakistan: An issue of causality. Pakistan Economic and Social Review, 46(1), 17-36.

Sarwar, S., Siddiqi, M., \& Butt, A. (2013). Role of institutions and economic growth in Asian countries. Developing Country Studies, 3(2), 80-90.

Self, S., \& Grabowski, R. (2004). Does education at all levels cause growth? India, a case study. Economics of Education Review, 23(1), 47-55.

Sinha, D., \& Sinha, T. (2008). Relationships among household saving, public saving, corporate saving and economic growth in India. Journal of International Development, 20(2), 181-186.

Stoilova, D. (2017). Tax structure and economic growth: Evidence from the European Union. Contaduría y Administración, 62(3), 1041-1057.

Szarowska, I. (2010). Changes in taxation and their impact on economic growth in the European Union. Acta Universitatis Agriculturae et Silviculturae Mendeleianae Brunensis , 59(2), 325-332.

Tanzi, V. (1989). The impact of macroeconomic policies on the level of taxation and the fiscal balance in developing countries. Staff Papers, 36(3), 633-656.

Teera, J. M., \& Hudson, J. (2004). Tax performance: A comparative study. Journal of International Development, 16(6), 785-802.

Torgler, B., \& Schneider, F. (2009). The impact of tax morale and institutional quality on the shadow economy. Journal of Economic Psychology, 30(2), 228-245. 
Verma, R., Wilson, E., \& Pahlavani, M. (2007). The role of capital formation and saving in promoting economic growth in Iran. $35^{\text {th }}$ Australian Conference of Economists, Curtin University of Technology, Perth, Austrialia.

Wenli, L., \& Sarte, P. D. (2004). Progressive taxation and long-run growth. American Economic Review, 94(5), 1705-1716.

Widmalm, F. (2001). Tax structure and growth: Are some taxes better than others? Public Choice, 107(34), 199-219.

Windmeijer, F. (2005). A finite sample correction for the variance of linear efficient two step GMM estimators. Journal of Econometrics, 126, 25-51.

Wintoki, M. B., Linck, J. S., \& Netter, J. M. (2012). Endogeneity and the dynamics of internal corporate governance. Journal of Financial Economics, 105(3), 581-606.

Wooldridge, J. M. (2016). Introductory econometrics: A modern approach (Nelson Education).

Xing, J. (2012). Tax structure and growth: How robust is the empirical evidence? Economics Letters, 117(1), 379-382.

Yanikkaya, H., \& Turan, T. (2020). Tax Structure and economic growth: Do differences in income level and government effectiveness matter? The Singapore Economic Review, 65(1), 217-237.

Y1lmaz, E. (2013). Competition, taxation and economic growth. Economic Modelling, 35, 134-139.

Zellner, A., \& Ngoie, K. (2015). Evaluation of the effect of reduced personal and corporate tax rates on growth rates of the U.S economy, Econometric Reviews, 34(1), 56-81. 


\section{Appendix 1}

Table-A1: List of 20 Sample Countries

$\begin{array}{llll}\text { Armenia } & \text { Indonesia } & \text { Malaysia } & \text { Russian Federation } \\ \text { Azerbaijan } & \text { Iran } & \text { Mongolia } & \text { Sri Lanka } \\ \text { Bangladesh } & \text { Jordan } & \text { Myanmar } & \text { Thailand } \\ \text { China } & \text { Kazakhstan } & \text { Pakistan } & \text { Turkey } \\ \text { India } & \text { Lebanon } & \text { Philippines } & \text { Vietnam }\end{array}$

Table-A2 Description of variables

\begin{tabular}{|c|c|c|c|c|c|c|}
\hline Variables & Description & Mean & Std. & Min & Max & Sources \\
\hline GR & Annual percentage growth rate of GDP & 5.11 & 4.75 & -15.58 & 25.80 & WDI (World \\
\hline $\mathrm{SSe}$ & $\begin{array}{l}\text { Total secondary school enrolment ratio as a } \\
\text { proxy of human capital }\end{array}$ & 72.11 & 21.95 & 22.61 & 127.99 & $\begin{array}{l}\text { Developmen } \\
\text { t Indicators) }\end{array}$ \\
\hline $\mathrm{GFc}$ & $\begin{array}{l}\text { gross fixed capital formation as } \% \text { of GDP } \\
\text { to measure the country's rate of investment }\end{array}$ & 25.95 & 6.36 & 13.39 & 46.49 & \\
\hline FDin & $\begin{array}{l}\text { foreign direct investment, net inflows as \% } \\
\text { of GDP }\end{array}$ & 3.87 & 5.38 & -5.13 & 43.93 & \\
\hline GSg & Gross saving as \% of GDP & 26.74 & 10.53 & -3.39 & 50.66 & \\
\hline Popg & Annual population growth rate & 1.37 & 1.13 & -1.77 & 5.80 & \\
\hline INst. & $\begin{array}{l}\text { Political and economic institutional } \\
\text { composite indicator }\end{array}$ & -0.33 & 0.81 & -2.33 & 1.58 & ICRG \\
\hline DiTx & $\begin{array}{l}\text { Direct Taxes (including social security } \\
\text { contribution) }\end{array}$ & 5.74 & 3.55 & 0.00 & 16.20 & $\begin{array}{l}\text { ICTD by } \\
\text { (UNU- }\end{array}$ \\
\hline TxIpcT & $\begin{array}{l}\text { Taxes on Income, Profits \& Capital Gains } \\
\text { (total) }\end{array}$ & 4.73 & 2.53 & 0.83 & 11.25 & WIDER) \\
\hline Tx-PiT & TOIP\&CG o/w PIT-personal & 1.45 & 1.17 & 0.00 & 6.22 & \\
\hline Tx-CiT & TOIP\&CG o/w CIT-corporate & 2.76 & 2.23 & 0.00 & 12.25 & \\
\hline TxPW & Taxes on Payroll \& Workforce & 0.01 & 0.05 & 0.00 & 0.45 & \\
\hline PrTx & Property Taxes & 0.22 & 0.35 & 0.00 & 1.83 & \\
\hline IndTx & Indirect Taxes & 8.15 & 4.06 & 0.00 & 16.98 & \\
\hline TxGsT & Taxes on Goods and Services(total) & 5.98 & 3.02 & 0.57 & 13.02 & \\
\hline Gst & $\begin{array}{l}\text { TOG\&S o/w General (Sales, VAT, } \\
\text { Turnover, TFCT) }\end{array}$ & 4.09 & 2.23 & 0.01 & 10.61 & \\
\hline Vat & TOG\&S VAT & 3.09 & 2.28 & 0.00 & 8.66 & \\
\hline TxInt. & Taxes on International Trade & 1.92 & 1.59 & 0.14 & 8.61 & \\
\hline OthTx & Other Taxes & 0.85 & 0.99 & 0.00 & 4.64 & \\
\hline
\end{tabular}

Source: Author's calculation 